\title{
Activated Tumor-infiltrating Fibroblasts Predict Worse Prognosis in Breast Cancer Patients
}

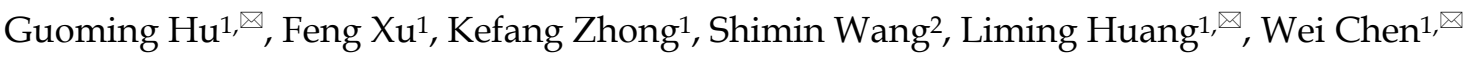 \\ 1. Department of General Surgery (Breast and Thyroid Surgery), Shaoxing People's Hospital; Shaoxing Hospital, Zhejiang University School of Medicine, \\ 312000, Zhejiang, China. \\ 2. Department of Nephrology, Shaoxing People's Hospital; Shaoxing Hospital, Zhejiang University School of Medicine, 312000, Zhejiang, China. \\ $\triangle$ Corresponding authors: Guoming Hu: E-mail: hgmplj@126.com; Liming Huang: E-mail: shaoxinghlm@126.com; Wei Chen: E-mail: cwzjsx5018@163.com. \\ (c) Ivyspring International Publisher. This is an open access article distributed under the terms of the Creative Commons Attribution (CC BY-NC) license \\ (https://creativecommons.org/licenses/by-nc/4.0/). See http://ivyspring.com/terms for full terms and conditions.
}

Received: 2018.06.22; Accepted: 2018.08.23; Published: 2018.09.08

\begin{abstract}
Purpose: Activated tumor-infiltrating fibroblasts were significantly associated with survival of cancer patients. However, they are heterogeneous population, and the prognostic role of these cells in human breast cancer still remains controversial. Herein, we performed the meta-analysis to better understand the role of these cells in prognosis prediction for breast cancer patients.

Methods: We searched PubMed and EBSCO to identify the studies evaluating the association of intratumoral activated fibroblast density detected by immunohistochemical (IHC) method and overall survival (OS) and/or disease-free survival (DFS) in breast cancer patients, then computed extracted data into hazard ratios (HRs) for OS, DFS and clinicopathological features such as lymph node metastasis, TNM stage with STATA 12.0.

Results: A total of 3680 patients with breast cancer from 15 published studies were incorporated into this meta-analysis. We found that the infiltration of activated fibroblasts significantly decreased overall survival (OS) and disease-free survival (DFS) in patients. In stratified analyses, high density of FSP-1+ or podoplanin ${ }^{+}$ fibroblasts was significantly associated with worse OS; while $\alpha-S M A^{+}$or podoplanin ${ }^{+}$fibroblast infiltration was associated with worse DFS in breast cancer. In addition, elevated number of activated tumor-infiltrating fibroblasts significantly correlated with lymph node metastasis and poor tumor differentiation of patients.

Conclusion: The infiltration of activated fibroblasts, especially the FSP-1+ or podoplanin+ fibroblasts leads to worse clinical outcome in breast cancer patients, implicating that it is a valuable prognostic biomarker and targeting it may have a potential for effective treatment.
\end{abstract}

Key words: activated fibroblasts; tumor microenvironment; breast cancer; prognosis; meta-analysis

\section{Introduction}

Breast cancer is the second leading cause of cancer-related deaths in females [1]. Tumor microenvironment (TME) linked closely with the initiation, promotion, and progression of breast cancer [2]. Fibroblasts, as the important component of the TME, are often activated by a multitude of stimuli including certain cytokines released by cancer cells [3]. Multitudinous studies have demonstrated that activated tumor-infiltrating fibroblasts were significantly associated with survival of cancer patients.

Although tumor-infiltrating fibroblasts are heterogeneous population, there are no highly specific markers to delineate potential heterogeneous subpopulations of them. Until recently, several markers such as alpha smooth muscle actin (a-SMA), fibroblast activation protein alpha (FAP- $\alpha$ ), fibroblast-specific protein-1 (FSP-1) (also known as S100A4), platelet-derived growth factor beta receptor (PDGFR- $\beta$ ) and podoplanin (PDPN) have been used to identify the activated fibroblasts [4]. Currently, depletion of activated fibroblasts has been utilized to restrain cancer including colon cancer in preclinical studies, yielding somewhat promising results [5-7]. However, in patients with breast cancer, discordant results have been reported concerning the prognostic value of activated fibroblast infiltration, which may play a negative [8-11], positive [12], or non-predictive 
[13-17] role in combating cancer. Thus, it needs in-depth assessment. Furthermore, the potential of these cells as a prognostic biomarker and targeted immunotherapy is essential to be explored.

We performed this meta-analysis to clarify the association between the infiltration of activated fibroblasts and outcomes such as overall survival (OS) and disease-free survival (DFS) in breast cancer patients.

\section{Materials and Methods}

\section{Search strategy}

PubMed and EBSCO were searched for studies to evaluate the density of tumor-infiltrating activated fibroblasts and survival in breast cancer patients from 1980 to April 30th 2018. The keywords adopted for search were (fibroblasts [Title/ Abstract]) AND (breast [Title/Abstract] OR mammary [Title/Abstract]) AND (neoplasms [Title/Abstract] OR tumor [Title/ Abstract] OR cancer [Title/Abstract] OR carcinoma [Title/Abstract]).

\section{Inclusion and exclusion criteria}

In this meta-analysis, the inclusion criteria were: studies must have (1) been published as original articles; (2) investigated breast cancer patients; (3) detected activated fibroblasts in primary tumor specimens with immunohistochemistry (IHC); (4) provided hazard ratios (HRs) with 95\% confidence interval (CI), or Kaplan - Meier curves of high and low density of activated fibroblasts with OS, and/or DFS; (5) been published in English.

The exclusion criteria were: studies (1) were not published as research articles or full texts including commentary, case report, letters to editors and conference abstracts; (2) didn't provide sufficient data to estimate HRs; (3) detected activated fibroblasts not with marker ' $a-S M A$ ' etc mentioned above, or in metastatic tissues.

\section{Endpoints}

In this meta-analysis, we recorded OS and DFS as the primary and second endpoint respectively. OS was defined as the time from the date of the first curative operation to the date of the last follow-up, or death from any cause; while DFS was the time from the date of the first curative surgery to the date of the first loco-regional or systemic relapse, or death without any type of relapse.

\section{Data extraction}

GM.H. and KF.Z. independently reviewed and extracted data such as first author's name, number of patients, median age, time of follow-up, method and markers used to quantify activated fibroblasts as well as cut-off value to define high density of these cells. OS, DFS and clinicopathological information including tumor, node, metastasis (TNM) stage and tumor differentiation etc were extracted from the text, tables, or Kaplan - Meier curves.

\section{Quality assessment}

Two independent authors evaluated the quality of included cohort studies with Newcastle-Ottawa Scale (NOS) [18], and achieved consensus for each item under the help of third author. A total score of 6 or more points was considered high quality.

\section{Statistical Analysis}

We combined extracted data into meta-analyses with STATA 12.0 analysis software (Stata Corporation, College Station, TX, USA). Statistical heterogeneity was assessed with the chi-squared based Q-test or $I^{2}[19]$. Data were combined based on the random-effect model in the presence of heterogeneity [20], otherwise, the fixed-effect model was applied [21]. Sensitivity analysis, Begg's funnel plot and Egger's test [22] were applied to probe the influence of each study on the pooled result and potential publication bias respectively. All $P$ values were two-sided and less than 0.05 are considered statistically significant.

\section{Results}

\section{Search results and description of studies}

11317 records were retrieved and the results were exhibited in Fig. S1. We ultimately identified 15 studies containing 3680 breast cancer patients for the assessment of activated fibroblasts [8-17, 23-27], and then evaluated all these studies with the Newcastle-Ottawa Scale (NOS). Characteristics of included studies being in accordance with the inclusion criteria and suitable for data consolidation were shown in Table 1 and Table S1.

\section{Meta-analyses}

\section{Overall survival (OS)}

In this meta-analysis, the pooled result indicated that activated fibroblast infiltration significantly decreased OS $(\mathrm{HR}=1.99,95 \%$ CI 1.45 to $2.74, P<$ 0.001) in breast cancer patients (Fig. 1).

In stratified analyses by different subsets of tumor-infiltrating fibroblasts, as shown in Fig. 2, pooled results showed that high density of tumor-infiltrating FSP-1+ fibroblasts was significantly associated with worse OS in patients (HR $=1.67,95 \%$ CI 1.07 to 2.59, $P=0.023$ ); Similar result was observed between $\mathrm{PDPN}^{+}$fibroblast infiltration and $\mathrm{OS}$ in breast cancer $(\mathrm{HR}=2.46,95 \% \mathrm{CI} 1.44$ to $2.76, P<$ 
$0.001)$, with no heterogeneity being detected $\left(I^{2}=\right.$ $0.0 \%, P=0.840)$. However, there was no significant association between the infiltration of a-SMA ${ }^{+}$ fibroblasts ( $\mathrm{HR}=3.13,95 \% \mathrm{CI} 0.96$ to $10.27, P=0.059)$, or FAP- $\mathrm{a}^{+}$fibroblasts (HR $=0.40,95 \% \mathrm{CI} 0.04$ to $3.88, P$ $=0.433)$ or PDGFR- $\beta^{+}$fibroblasts $(\mathrm{HR}=2.68,95 \% \mathrm{CI}$ 0.79 to $9.13, P=0.114$ ) and $O S$ in patients.

\section{Disease-free survival (DFS)}

Meta-analysis showed that the infiltration of activated fibroblasts was significantly associated with decreased DFS $(\mathrm{HR}=1.84,95 \%$ CI 1.25 to $2.72, P=$ 0.002) in human breast cancer (Fig. 3).

In stratified analyses, we found that increased density of tumor-infiltrating a-SMA ${ }^{+}$fibroblasts was significantly associated with worse DFS in breast cancer $(\mathrm{HR}=2.89,95 \% \mathrm{CI} 1.34$ to $6.25, P=0.007)$, with no heterogeneity existing among included studies $\left(I^{2}=\right.$ $0.0 \%, P=0.339)$. Similar result was observed between $\mathrm{PDPN}^{+}$fibroblast infiltration and DFS in patients (HR $=2.26,95 \%$ CI 1.56 to $3.28, P<0.001)$. Nevertheless, there was no significant association between FSP-1+ fibroblast infiltration and DFS (HR $=1.80,95 \%$ CI 0.94 to $3.43, P=0.074$ ) in breast cancer patients (Fig. 4).

In addition, we found that increased density of these cells was significantly associated with clinicopathological features such as lymph node metastasis $(\mathrm{OR}=1.43,95 \%$ CI 1.02 to $2.00, P=0.036)$, poor tumor differentiation (OR $=0.35,95 \% \mathrm{CI} 0.20$ to $0.62, P<0.001$ ) and negative estrogen receptor (ER) status (OR $=0.59,95 \%$ CI 0.39 to $0.88, P=0.009)$, but not with TNM stage (OR $=0.88,95 \%$ CI 0.48 to $1.63, P$ $=0.690$ ) of patients (Fig. S2).

\section{Sensitivity analysis}

Sensitivity analysis indicated that each included study had no influence on the overall HR for OS or DFS.

\section{Publication bias}

There was no publication bias existing between activated tumor-infiltrating fibroblasts and OS $(P=$ $0.596)$ or DFS $(P=0.795)$ in patients by Funnel plot and Egger's test.

Table 1. Main characteristics of the included studies.

\begin{tabular}{|c|c|c|c|c|c|c|c|c|c|c|c|}
\hline Study & Year & Tumor type & $\begin{array}{l}\text { No. of } \\
\text { Patients }\end{array}$ & $\begin{array}{l}\text { Median age } \\
\text { (range) } \\
\text { (year) }\end{array}$ & Cut-offs & $\begin{array}{l}\text { Marker for } \\
\text { activated } \\
\text { fibroblasts }\end{array}$ & $\begin{array}{l}\text { Activated } \\
\text { fibroblast } \\
\text { density: H / L }\end{array}$ & $\begin{array}{l}\text { Tumor } \\
\text { stage }\end{array}$ & $\begin{array}{l}\text { Median } \\
\text { follow-up date } \\
\text { (months) }\end{array}$ & Survival & $\begin{array}{l}\text { Quality } \\
\text { Score } \\
\text { (NOS) }\end{array}$ \\
\hline $\begin{array}{l}\text { Yang, Z.T. etal } \\
{[23]}\end{array}$ & 2017 & $\begin{array}{l}\text { Invasive breast } \\
\text { cancer }\end{array}$ & 150 & $\begin{array}{l}\leq 50: 68 \% \\
>50: 32 \%\end{array}$ & $\begin{array}{l}\geq 20 \% \text { of the stroma } \\
/ \mathrm{HPF}\end{array}$ & $\begin{array}{l}\text { a-SMA } \\
\text { FSP-1 }\end{array}$ & $\begin{array}{l}108 / 42 \\
58 / 92\end{array}$ & NR & $68(2,108)$ & OS & 8 \\
\hline $\begin{array}{l}\text { Yamashita, M. } \\
\text { etal [24] }\end{array}$ & 2012 & $\begin{array}{l}\text { Invasive breast } \\
\text { cancer }\end{array}$ & 60 & NR & $\begin{array}{l}>8.48 \% \text { of the } \\
\text { spindle-shaped } \\
\text { cells/field area }\end{array}$ & a-SMA & $25 / 35$ & I - III & $74.8 \pm 19.3$ & OS, DFS & 7 \\
\hline $\begin{array}{l}\text { Surowiak, } \mathrm{P} . \\
\text { etal [13] }\end{array}$ & 2007 & $\begin{array}{l}\text { Invasive breast } \\
\text { cancer }\end{array}$ & 45 & 61.47 & $\begin{array}{l}\geq 10 \% \text { of stromal } \\
\text { fibroblasts / HPF }\end{array}$ & a-SMA & $28 / 17$ & I - III & $\geq 96$ & OS, DFS & 8 \\
\hline $\begin{array}{l}\text { Ariga, N. etal } \\
{[12]}\end{array}$ & 2001 & $\begin{array}{l}\text { Invasive breast } \\
\text { cancer }\end{array}$ & 112 & NR & $\begin{array}{l}\geq 10 \% \text { of the stroma } \\
/ \mathrm{HPF}\end{array}$ & FAP- $\alpha$ & $61 / 51$ & NR & NR & OS, DFS & 7 \\
\hline $\begin{array}{l}\text { Jung, Y.Y. etal } \\
\text { [9] }\end{array}$ & 2015 & $\begin{array}{l}\text { Invasive breast } \\
\text { cancer }\end{array}$ & 642 & $\begin{array}{l}\leq 50: 60.3 \% \\
>50: 39.7 \%\end{array}$ & $\begin{array}{l}\geq 10 \% \text { of the stroma } \\
/ \mathrm{HPF}\end{array}$ & FSP-1 & $189 / 453$ & I - III & $68.3 \pm 30.1$ & OS, DFS & 7 \\
\hline $\begin{array}{l}\text { Egeland, E.V. } \\
\text { etal [10] }\end{array}$ & 2016 & $\begin{array}{l}\text { Early-stage } \\
\text { breast cancer }\end{array}$ & 291 & $60(19,93)$ & $>11 \%$ of the stroma & FSP-1 & $44 / 247$ & I-IIA & $\begin{array}{l}163.2(144, \\
188.4)\end{array}$ & Os & 8 \\
\hline $\begin{array}{l}\text { Martinez, L.M. } \\
\text { etal [14] }\end{array}$ & 2015 & $\begin{array}{l}\text { Early-stage } \\
\text { breast cancer }\end{array}$ & 53 & $(42,80)$ & $\begin{array}{l}\geq 10 \% \text { of the stroma } \\
/ \mathrm{HPF}\end{array}$ & FSP-1 & $23 / 30$ & I-IIA & NR & OS & 7 \\
\hline $\begin{array}{l}\text { Kim, H.M. etal } \\
{[15]}\end{array}$ & 2016 & $\begin{array}{l}\text { malignant } \\
\text { breast } \\
\text { phyllodes } \\
\text { tumor }\end{array}$ & 16 & $47.6 \pm 12.9$ & $>30 \%$ of the stroma & PDGFR- $\beta$ & $10 / 6$ & NR & NR & OS & 6 \\
\hline $\begin{array}{l}\text { Paulsson, J. etal } \\
{[25]}\end{array}$ & 2009 & $\begin{array}{l}\text { Invasive breast } \\
\text { cancer }\end{array}$ & 289 & $64.2(27,96)$ & $\begin{array}{l}\geq 10 \% \text { of stromal } \\
\text { fibroblasts } / \mathrm{HPF}\end{array}$ & PDGFR- $\beta$ & $100 / 189$ & NR & $106(0,207)$ & OS, DFS & 7 \\
\hline \multirow{2}{*}{$\begin{array}{l}\text { Park, C.K. etal } \\
{[16]}\end{array}$} & \multirow[t]{2}{*}{2016} & \multirow{2}{*}{$\begin{array}{l}\text { Invasive breast } \\
\text { cancer }\end{array}$} & 628 & $67.7(39,91)$ & \multirow{2}{*}{$\begin{array}{l}\geq 10 \% \text { of the stroma } \\
/ \mathrm{HPF}\end{array}$} & FSP-1 & $425 / 203$ & \multirow[t]{2}{*}{ I - III } & \multirow[t]{2}{*}{ NR } & \multirow[t]{2}{*}{ OS, DFS } & \multirow[t]{2}{*}{8} \\
\hline & & & 524 & $\begin{array}{l}<50: 55.8 \% \\
\geq 50: 44.2 \%\end{array}$ & & PDPN & $101 / 423$ & & & & \\
\hline \multirow[t]{3}{*}{$\begin{array}{l}\text { Park, S.Y. etal } \\
{[8]}\end{array}$} & \multirow[t]{3}{*}{2015} & $\begin{array}{l}\text { Invasive breast } \\
\text { cancer }\end{array}$ & 642 & $\begin{array}{l}\leq 50: 58.5 \% \\
>50: 41.5 \%\end{array}$ & \multirow[t]{3}{*}{$\begin{array}{l}\geq 10 \% \text { of the stroma } \\
/ \mathrm{HPF}\end{array}$} & FSP-1 & $189 / 453$ & \multirow[t]{3}{*}{ I - III } & \multirow[t]{3}{*}{$68.3 \pm 30.1$} & \multirow[t]{3}{*}{ OS } & \multirow[t]{3}{*}{8} \\
\hline & & $\begin{array}{l}\text { Luminal A } \\
\text { breast cancer }\end{array}$ & 275 & $\begin{array}{l}\leq 50: 60.3 \% \\
>50: 39.7 \%\end{array}$ & & PDPN & $40 / 235$ & & & & \\
\hline & & $\begin{array}{l}\text { Luminal B } \\
\text { breast cancer }\end{array}$ & 152 & $\begin{array}{l}\leq 50: 58.5 \% \\
>50: 41.5 \%\end{array}$ & & FAP- $\alpha$ & $5 / 147$ & & & & \\
\hline Pula, B. etal [17] & 2013 & $\begin{array}{l}\text { Invasive breast } \\
\text { cancer }\end{array}$ & 104 & $55.9 \pm 11.6$ & $\begin{array}{l}\text { immunoreaction score } \\
>3\end{array}$ & PDPN & $74 / 30$ & I - III & $(1,125)$ & OS & 7 \\
\hline $\begin{array}{l}\text { Schoppmann, } \\
\text { S.F. etal [11] }\end{array}$ & 2012 & $\begin{array}{l}\text { Invasive breast } \\
\text { cancer }\end{array}$ & 367 & $61 \pm 13$ & $\begin{array}{l}\geq 10 \% \text { of the stroma } \\
/ \mathrm{HPF}\end{array}$ & PDPN & $33 / 334$ & I - III & $120(1,329)$ & OS, DFS & 8 \\
\hline Pula, B. etal [26] & 2011 & $\begin{array}{l}\text { Invasive breast } \\
\text { cancer }\end{array}$ & 117 & $56.6 \pm 11.3$ & $\geq$ grade 1 & PDPN & $96 / 21$ & $\mathrm{I}-\mathrm{IV}$ & $(1,125)$ & OS, DFS & 7 \\
\hline $\begin{array}{l}\text { Cai, D.Y. etal } \\
\text { [27] }\end{array}$ & 2017 & $\begin{array}{l}\text { Invasive breast } \\
\text { cancer }\end{array}$ & 164 & $52.0 \pm 12.6$ & $\begin{array}{l}\geq 10 \% \text { of the stroma } \\
/ \mathrm{HPF}\end{array}$ & PDPN & $72 / 92$ & I - III & $42(1,84)$ & DFS & 7 \\
\hline
\end{tabular}

H: high; L: low 


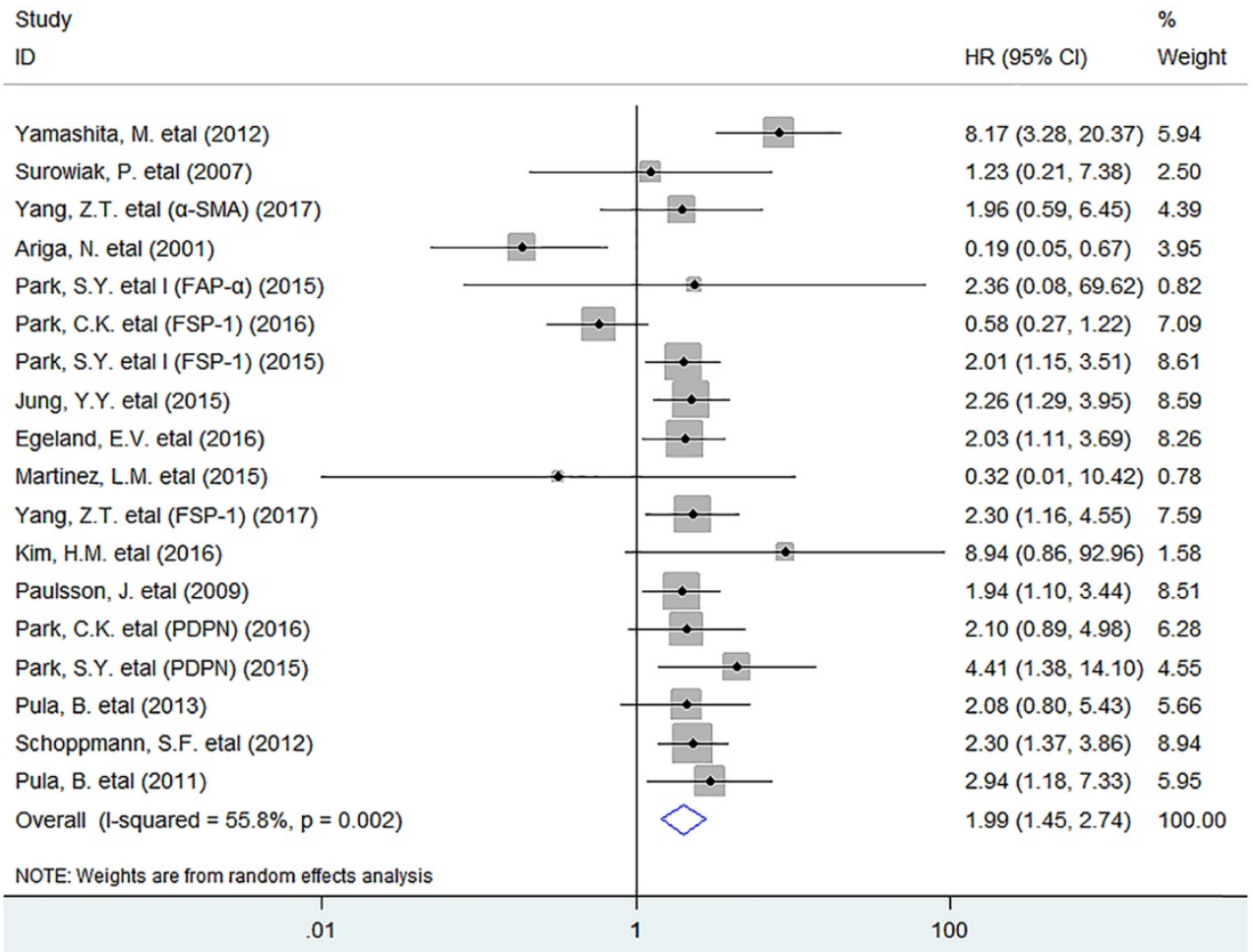

Fig. 1. Forest plots describing HR of the association between activated fibroblast infiltration and OS in breast cancer patients.

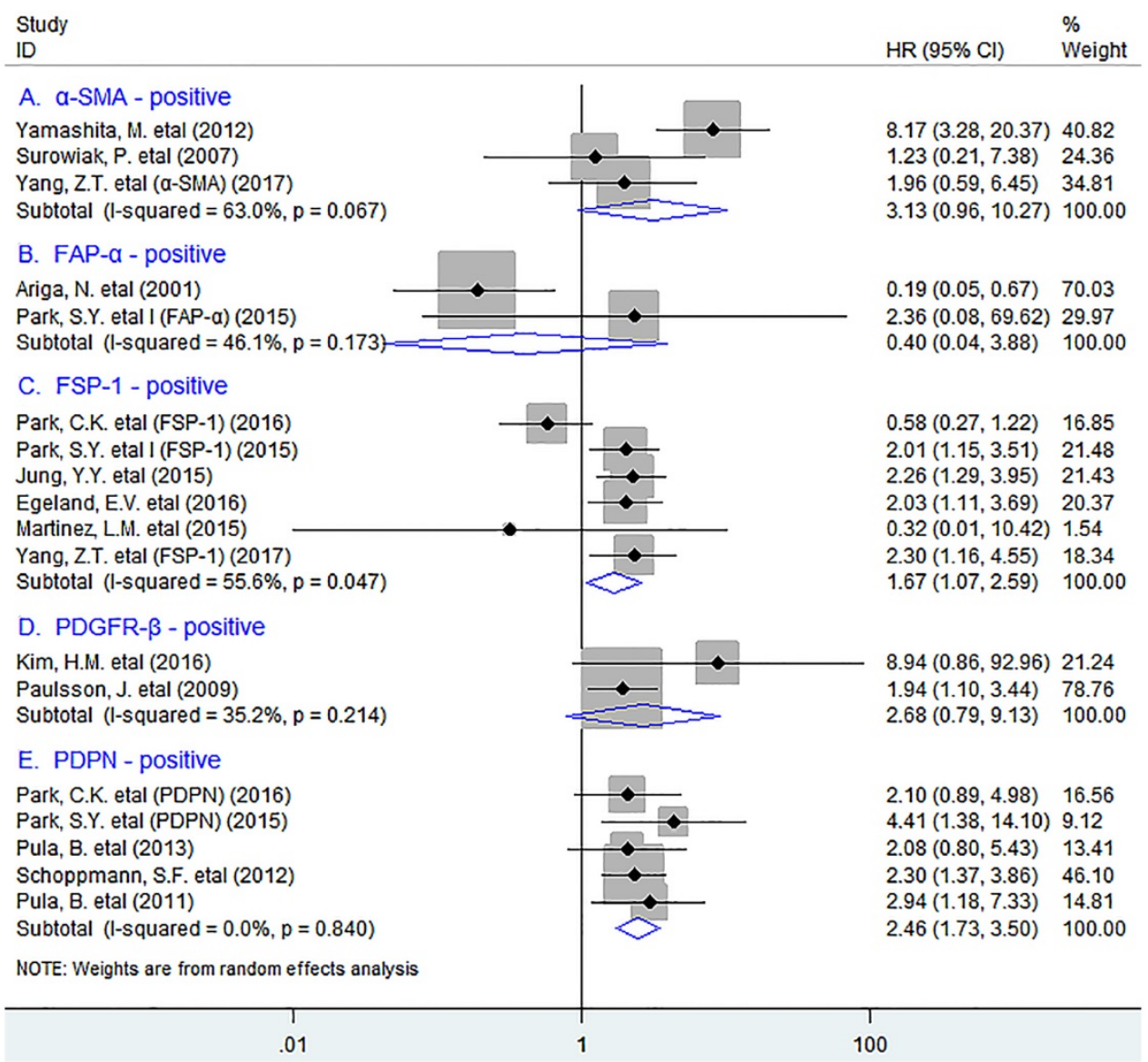

Fig. 2. Stratified analyses describing HRs of the association between the infiltration of different subpopulations of activated fibroblasts and OS. 


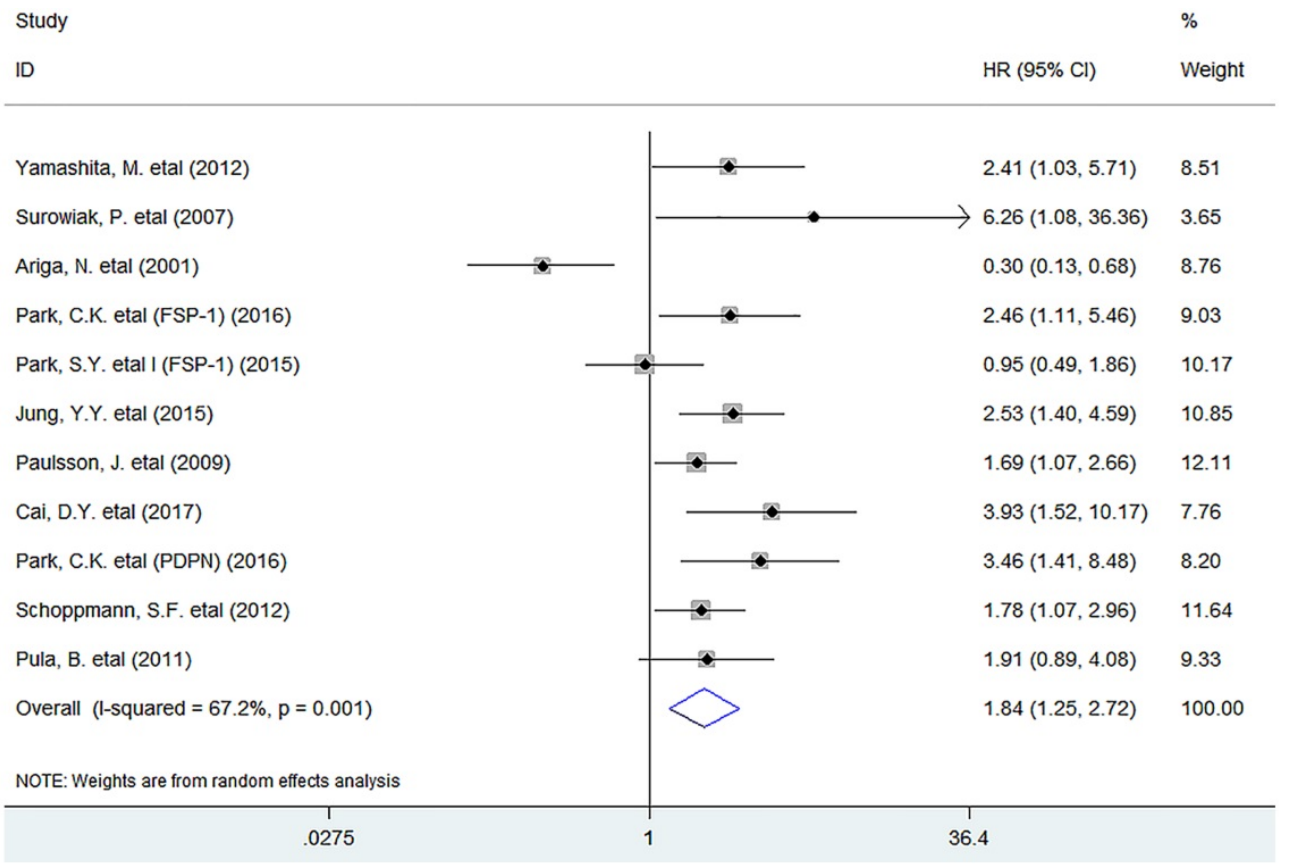

Fig. 3. Forest plots describing HR of the association between activated fibroblast infiltration and DFS in breast cancer patients.

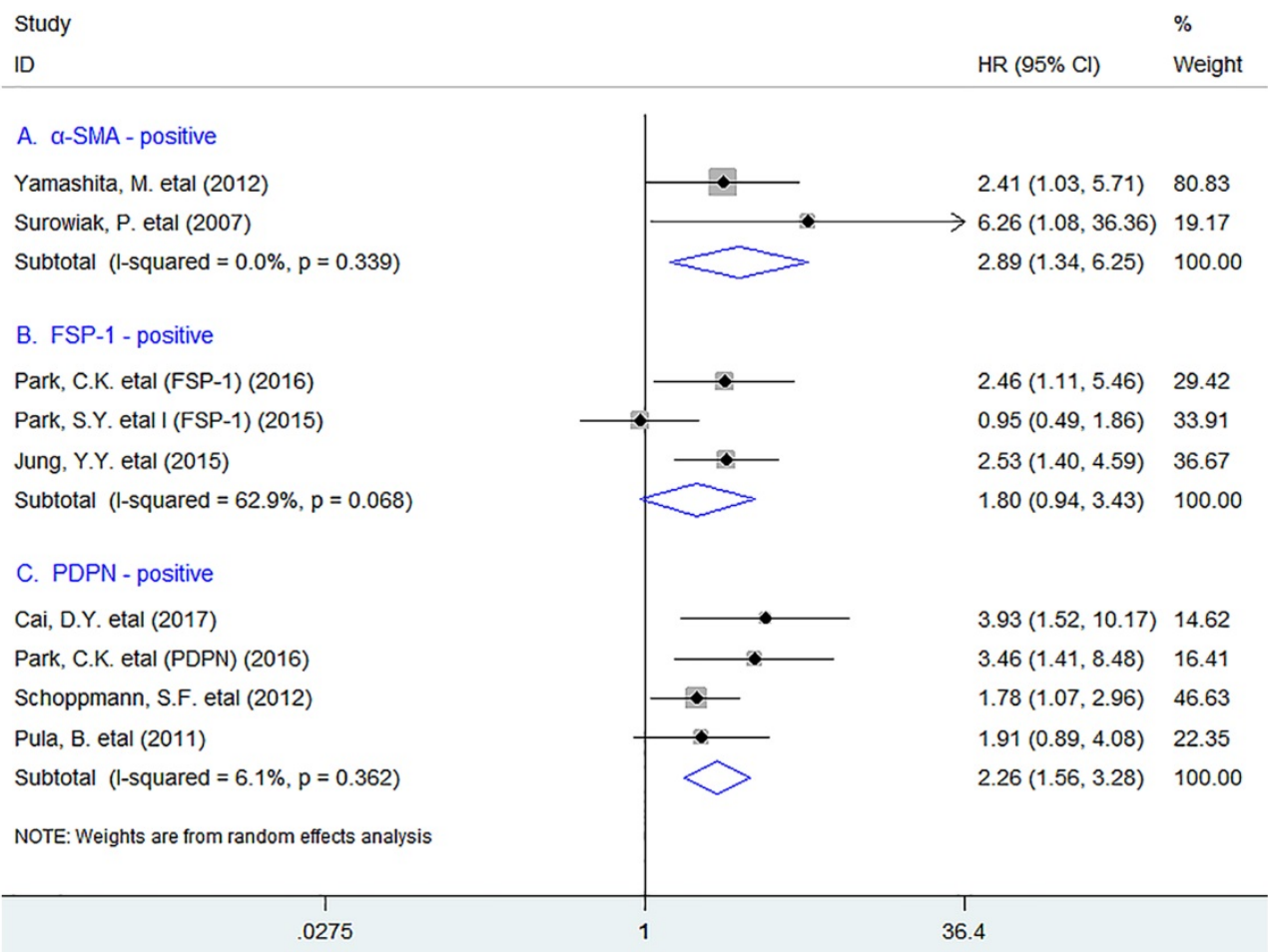

Fig. 4. Stratified analyses describing HRs of the association between the infiltration of different subpopulations of activated fibroblasts and DFS.

\section{Discussion}

Fibroblasts are traditionally implicated and well recognized in wound healing and tissue fibrosis. In the past decades, although many studies have correlated activated tumor-infiltrating fibroblasts and prognosis of breast cancer patients, their results were not consistent even controversial. In the present meta-analysis, we found that the infiltration of activated fibroblasts, especially the FSP $-1^{+}$or $\mathrm{PDPN}^{+}$ fibroblasts had a negative prognostic effect associated with survival in breast cancer. In addition, increased density of activated fibroblasts was significantly associated with lymph node metastasis and poor tumor differentiation of breast cancer. Hence, we think these findings provide meaningful statistical evidence to exhibit the negative prognostic role of these cells in breast cancer patients. 
The following reasons could possibly be responsible for the close association between increased activated tumor-infiltrating fibroblasts and decreased survival of patients presented in this study: Activated fibroblasts are able to promote tumor cell invasion, proliferation and survival through releasing growth factors, cytokines [28], and extracellular matrix (ECM)-degrading proteases such as matrix metalloproteinases (MMPs) [29]. These cells can synthesize and release angiogenic factors including IL-8 and TNF- $a$ as well as VEGF which promote neoangiogenesis thereby facilitating tumor growth.[30] In addition, they can also produce amount of immunosuppressive cytokines such as TGF- $\beta 1$, IL-6 and IL-10 to inhibit antitumor immunity mediated by effector $\mathrm{T}$ cells [30], recruit tumor-associated macrophages (TAMs) via CCL2 secretion, and decrease the activation of effector $\mathrm{T}$ cells through their acquisition of adhesion molecules such as intercellular adhesion molecule -1 (ICAM-1) [31] thereby establishing immunosuppressive microenvironment. Thus, it is reasonable to conclude that the activated tumor-infiltrating fibroblasts are able to promote tumor progression thereby decreasing survival.

Some markers such as a-SMA, FAP-a and FSP-1 are considered to the specific markers, especially a-SMA is the most wildly used to identify the activated fibroblasts; whereas PDGFR- $\beta$ and PDPN are the non-specific markers as they are also expressed in other cells including endotheliocytes [32]. Interestingly, different activated markers on fibroblasts are deemed to exhibit differential and unique significance in clinical practice. For instance, FAP- $\mathrm{a}^{+}$fibroblasts have been thought to be involved in modulation of ECM and tumor cell invasion through increasing levels of fibronectin and collagen fiber organization [33]; while PDGFR- $\beta^{+}$fibroblasts were shown to be associated with metastastic spread and high interstitial fluid pressure [34, 35], and FSP-1 ${ }^{+}$ fibroblasts promote metastastic colonization through VEGF-A production [36], and protection from carcinogens [37]. In addition, PDPN expressed in fibroblasts can enhance the ability of these cells to promote motility and survival of neighboring tumor cells through increased RhoA activity [38]; whereas the specific function of a-SMA ${ }^{+}$fibroblasts needs further investigation.

There were several limitations in this study. First, morphometric analyses for activated fibroblasts used in individual included studies were not consistent. In addition, studies with negative results may not be published, which may cause potential publication bias.
In conclusion, the infiltration of activated fibroblasts, especially the $\mathrm{FSP}-1^{+}$or podoplanin ${ }^{+}$ fibroblasts leads to an unfavorable clinical outcome in breast cancer patients, implicating that it is an effective prognostic biomarker and targeting it may be the novel therapeutic strategy for these patients.

\section{Abbreviations}

OS: overall survival; DFS: disease-free survival; $\mathrm{HR}$ : hazard ratio; OR: odds ratios; $\mathrm{Cl}$ : confidence interval; a-SMA: alpha smooth muscle actin; FAP-a: fibroblast activation protein alpha; FSP-1: fibroblastspecific protein-1; PDGFR- $\beta$ : platelet-derived growth factor beta receptor; PDPN: podoplanin; IHC: immunohistochemistry; TNM: tumor, node, metastasis; TME: tumor microenvironment; ER: estrogen receptor; ECM: extracellular matrix; NR: not reported; HPF: high power field.

\section{Supplementary Material}

Supplementary figures and table. http://www.jcancer.org/v09p3736s1.pdf

\section{Acknowledgments}

We thank all the members of the departments who helped in this study.

\section{Availability of data and materials}

The datasets supporting the conclusions of this article are included within the article.

\section{Funding}

This work was supported by the National Natural Science Foundation of China (Grant No. 81702803, GMH). This work was also granted from the project of Zhejiang Province Scientific Research Foundation of Traditional Chinese Medicine (Grant No. 2017ZB089, LMH) and Science and Technology Innovation Project of Shaoxing Health and Family Planning Program (Grant No. 2016CX002, WC).

\section{Authors' contributions}

GM.H. conceived of the study, participated in its design, extracted data, performed the statistical analysis and drafted the manuscript. KF.Z. participated in data extraction. F.X. and SM.W. participated in the statistical analysis. LM.H. and W.C. participated in the design of the study. All authors read and approved the final manuscript.

\section{Competing Interests}

The authors have declared that no competing interest exists. 


\section{References}

1. Siegel RL, Miller KD, Jemal A: Cancer statistics, 2018. CA: a cancer journal for clinicians 2018, 68(1):7-30.

2. Motz GT, Coukos G: The parallel lives of angiogenesis and immunosuppression: cancer and other tales. Nat Rev Immunol 2011, 11(10):702-711.

3. Kalluri R, Zeisberg M: Fibroblasts in cancer. Nature reviews Cancer 2006, 6(5):392-401.

4. Ohlund D, Elyada E, Tuveson D: Fibroblast heterogeneity in the cancer wound. J Exp Med 2014, 211(8):1503-1523.

5. Kraman M, Bambrough PJ, Arnold JN, Roberts EW, Magiera L, Jones JO, Gopinathan A, Tuveson DA, Fearon DT: Suppression of antitumor immunity by stromal cells expressing fibroblast activation protein-alpha. Science 2010, 330(6005):827-830

6. Wen Y, Wang CT, Ma TT, Li ZY, Zhou LN, Mu B, Leng F, Shi HS, Li YO, Wei $Y Q$ : Immunotherapy targeting fibroblast activation protein inhibits tumor growth and increases survival in a murine colon cancer model. Cancer science 2010, 101(11):2325-2332.

7. Ohshio Y, Teramoto K, Hanaoka J, Tezuka N, Itoh Y, Asai T, Daigo Y, Ogasawara K: Cancer-associated fibroblast-targeted strategy enhances antitumor immune responses in dendritic cell-based vaccine. Cancer science 2015, 106(2):134-142.

8. Park SY, Kim HM, Koo JS: Differential expression of cancer-associated fibroblast-related proteins according to molecular subtype and stromal histology in breast cancer. Breast cancer research and treatment 2015, 149(3):727-741.

9. Jung YY, Lee YK, Koo JS: Expression of cancer-associated fibroblast-related proteins in adipose stroma of breast cancer. Tumour Biol 2015, 36(11):8685-8695.

10. Egeland EV, Boye K, Park D, Synnestvedt M, Sauer T, Oslo Breast Cancer C, Naume B, Borgen E, Maelandsmo GM: Prognostic significance of S100A4-expression and subcellular localization in early-stage breast cancer. Breast cancer research and treatment 2017, 162(1):127-137.

11. Schoppmann SF, Berghoff A, Dinhof C, Jakesz R, Gnant M, Dubsky P, Jesch B, Heinzl H, Birner P: Podoplanin-expressing cancer-associated fibroblasts are associated with poor prognosis in invasive breast cancer. Breast cancer research and treatment 2012, 134(1):237-244.

12. Ariga N, Sato E, Ohuchi N, Nagura H, Ohtani H: Stromal expression of fibroblast activation protein/seprase, a cell membrane serine proteinase and gelatinase, is associated with longer survival in patients with invasive ductal carcinoma of breast. Int J Cancer 2001, 95(1):67-72.

13. Surowiak P, Murawa D, Materna V, Maciejczyk A, Pudelko M, Ciesla S, Breborowicz J, Murawa P, Zabel M, Dietel M et al: Occurence of stromal myofibroblasts in the invasive ductal breast cancer tissue is an unfavourable prognostic factor. Anticancer Res 2007, 27(4C):2917-2924.

14. Martinez LM, Labovsky V, Calcagno ML, Davies KM, Garcia Rivello $\mathrm{H}_{\text {, }}$ Bianchi MS, Wernicke A, Fernandez Vallone VB, Chasseing NA: CD105 expression on CD34-negative spindle-shaped stromal cells of primary tumor is an unfavorable prognostic marker in early breast cancer patients. PLoS One 2015, 10(3):e0121421.

15. Kim HM, Lee YK, Koo JS: Expression of CAF-Related Proteins Is Associated with Histologic Grade of Breast Phyllodes Tumor. Disease markers 2016, 2016:4218989.

16. Park CK, Jung WH, Koo JS: Expression of cancer-associated fibroblast-related proteins differs between invasive lobular carcinoma and invasive ductal carcinoma. Breast cancer research and treatment 2016, 159(1):55-69.

17. Pula B, Wojnar A, Witkiewicz W, Dziegiel P, Podhorska-Okolow M: Podoplanin expression in cancer-associated fibroblasts correlates with VEGF-C expression in cancer cells of invasive ductal breast carcinoma. Neoplasma 2013, 60(5):516-524.

18. Stang A: Critical evaluation of the Newcastle-Ottawa scale for the assessment of the quality of nonrandomized studies in meta-analyses. European journal of epidemiology 2010, 25(9):603-605.

19. Higgins JP, Thompson SG, Deeks JJ, Altman DG: Measuring inconsistency in meta-analyses. Bmj 2003, 327(7414):557-560.

20. Kuritz SJ, Landis JR, Koch GG: A general overview of Mantel-Haenszel methods: applications and recent developments. Annual review of public health 1988, 9:123-160.

21. DerSimonian R, Kacker R: Random-effects model for meta-analysis of clinical trials: an update. Contemporary clinical trials 2007, 28(2):105-114.

22. Egger M, Davey Smith G, Schneider M, Minder C: Bias in meta-analysis detected by a simple, graphical test. Bmj 1997, 315(7109):629-634.

23. Yang Z, Ni W, Cui C, Fang L, Xuan Y: Tenascin C is a prognostic determinant and potential cancer-associated fibroblasts marker for breast ductal carcinoma. Experimental and molecular pathology 2017, 102(2):262-267.

24. Yamashita M, Ogawa T, Zhang X, Hanamura N, Kashikura Y, Takamura M, Yoneda M, Shiraishi T: Role of stromal myofibroblasts in invasive breast cancer: stromal expression of alpha-smooth muscle actin correlates with worse clinical outcome. Breast cancer 2012, 19(2):170-176.

25. Paulsson J, Sjoblom $\mathrm{T}$, Micke P, Ponten F, Landberg G, Heldin $\mathrm{CH}$, Bergh I, Brennan DJ, Jirstrom K, Ostman A: Prognostic significance of stromal platelet-derived growth factor beta-receptor expression in human breast cancer. The American journal of pathology 2009, 175(1):334-341.
26. Pula B, Jethon A, Piotrowska A, Gomulkiewicz A, Owczarek T, Calik J, Wojnar A, Witkiewicz W, Rys J, Ugorski M et al: Podoplanin expression by cancer-associated fibroblasts predicts poor outcome in invasive ductal breast carcinoma. Histopathology 2011, 59(6):1249-1260.

27. Cai D, Wu X, Hong T, Mao Y, Ge X, Hua D: CD61+ and CAF+ were found to be good prognosis factors for invasive breast cancer patients. Pathol Res Pract 2017, 213(10):1296-1301.

28. Bruzzese F, Hagglof C, Leone A, Sjoberg E, Roca MS, Kiflemariam S, Sjoblom T, Hammarsten P, Egevad L, Bergh A et al: Local and systemic protumorigenic effects of cancer-associated fibroblast-derived GDF15. Cancer Res 2014, 74(13):3408-3417.

29. Boire A, Covic L, Agarwal A, Jacques S, Sherifi S, Kuliopulos A: PAR1 is a matrix metalloprotease-1 receptor that promotes invasion and tumorigenesis of breast cancer cells. Cell 2005, 120(3):303-313.

30. Poggi A, Musso A, Dapino I, Zocchi MR: Mechanisms of tumor escape from immune system: role of mesenchymal stromal cells. Immunology letters 2014, 159(1-2):55-72.

31. Powell DW: Myofibroblasts: paracrine cells important in health and disease. Transactions of the American Clinical and Climatological Association 2000, 111:271-292; discussion 292-273.

32. Shiga $K$, Hara $M$, Nagasaki $T$, Sato $T$, Takahashi $H$, Takeyama $H$ : Cancer-Associated Fibroblasts: Their Characteristics and Their Roles in Tumor Growth. Cancers 2015, 7(4):2443-2458.

33. Lee HO, Mullins SR, Franco-Barraza J, Valianou M, Cukierman E, Cheng JD: FAP-overexpressing fibroblasts produce an extracellular matrix that enhances invasive velocity and directionality of pancreatic cancer cells. BMC Cancer 2011, 11:245.

34. Ehnman M, Missiaglia E, Folestad E, Selfe J, Strell C, Thway K, Brodin B, Pietras K, Shipley J, Ostman A et al: Distinct effects of ligand-induced PDGFRalpha and PDGFRbeta signaling in the human rhabdomyosarcoma tumor cell and stroma cell compartments. Cancer Res 2013, 73(7):2139-2149.

35. Pietras K, Ostman A, Sjoquist M, Buchdunger E, Reed RK, Heldin CH, Rubin $\mathrm{K}$ : Inhibition of platelet-derived growth factor receptors reduces interstitial hypertension and increases transcapillary transport in tumors. Cancer Res 2001, 61(7):2929-2934.

36. O'Connell JT, Sugimoto H, Cooke VG, MacDonald BA, Mehta AI, LeBleu VS, Dewar R, Rocha RM, Brentani RR, Resnick MB et al: VEGF-A and Tenascin-C produced by S100A4+ stromal cells are important for metastatic colonization. Proceedings of the National Academy of Sciences of the United States of America 2011, 108(38):16002-16007.

37. Zhang J, Chen L, Liu X, Kammertoens $\mathrm{T}$, Blankenstein $\mathrm{T}$, Oin $\mathrm{Z}$ : Fibroblast-specific protein 1/S100A4-positive cells prevent carcinoma through collagen production and encapsulation of carcinogens. Cancer Res 2013, 73(9):2770-2781.

38. Ito $\mathrm{S}$, Ishii $\mathrm{G}$, Hoshino A, Hashimoto $\mathrm{H}$, Neri $\mathrm{S}$, Kuwata $\mathrm{T}$, Higashi M, Nagai $\mathrm{K}$, Ochiai A: Tumor promoting effect of podoplanin-positive fibroblasts is mediated by enhanced RhoA activity. Biochem Biophys Res Commun 2012, 422(1):194-199. 